\title{
SOME METHODOLOGICAL DRILLING - BLASTING PARAMETERS IN THE EXCAVATION OF TUNNEL
}

\author{
Risto Dambov ${ }^{1}$, Nikolinka Doneva ${ }^{1}$, Marija Hadzi-Nikolova ${ }^{1}$
}

Received: October 12, 2017

Accepted: December 9, 2017

\begin{abstract}
The method of excavation tunnels, as infernal object depends primarily on the rock mass along the tunnel route, as well as rock mass in the nearby environment of the route. This paper presents a methodology for determining the drilling - blasting parameters in one of the various zones along the route of the tunnel. Furthermore, proposed here are the construction of a tunnel in three sections, pattern of the boreholes at the face, as well as the construction charged cut holes, auxiliary and contour blasting holes.
\end{abstract}

Keywords: Blast holes; Face; Charge construction;

\section{INTRODUCTION}

The significance and complexity of tunnel excavation is also reflected in the fact that a special science that deals with underground facilities construction, including tunnels has been developed (Vrkljan, 2003).

First step that determines success of tunnel excavation is the establishment of quasihomogeneous zones in the rock mass, located on the tunnel route (Merritt, 1972) then, the engineering geologic longitudinal profiles construction (Jovanovič, 1994). It is also necessary to determine physical and mechanical properties of rock masses along the route and nearby, the hydrological condition of terrain, as well as all the other characteristics on which the tunnel performance depends (Antičević, 2011). All these tests are required to perform the classification of rock mass along the tunnel route. (Laubscher, 1977; Bieniawski, 1989; Hoek, 2003; Doneva et al., 2013)

Based on the information related to the characteristics of the work environment or the rock type that are located on the route of the tunnel, preliminary analysis and calculation have been made, which allowed safe blasting during excavation the tunnel. The active length of the tunnel is $600 \mathrm{~m}$, and the profile size of $64.97 \mathrm{~m}^{2}$ (DAM-EXPLO, 2014).

Presented in this paper are only some ways of calculating, and drilling - blasting works, as integrated and indivisible working operations.

\footnotetext{
${ }^{1}$ Faculty of Natural and Technical Sciences, "Goce Delchev" University, Stip, Macedonia emails: nikolinka.doneva@ugd.edu.mk
} 
The choice of the technology for construction the tunnel depends, primarily, on the profile size of the object, geotechnical parameters and physical and mechanical characteristics of the working environment, the geology of the surrounding terrain and certainly, the equipment that the contractor has at his disposal.

Construction of structuress, such as tunnels may be done in two ways:

- by using conventional methods, using drilling and blasting operations (Olofsson, 1990) and

- by using modern rotating machines (TBM - tunnel boring machine).

This paper describes the first-mentioned technologies, which can be done in several ways:

- method of excavation the full profile (Doneva, 2013);

- method of excavation with two work faces;

- method of excavation with the expansion of a small part of the hall at the primary route;

- method of excavation in several sections (U.S. Army Corps of Engineering, 1997), which is described in this paper.

Modern tunnel boring machines (TBM) application is economically justified for routes longer than $1 \mathrm{~km}$ (Doneva 2005, Doneva et al. 2005).

\section{CHARACTERISTICS OF THE WORKING ENVIRONMENT}

In accordance with the methodology of defining the technical documentation for the construction of the tunnel, a certain volume of geological, geophysical and geotechnical tests work was carried out regarding the work environment along the route of the tunnel. The obtained data from these explorations are necessary for accurate definition of drilling - blasting parameters.

\subsection{Geo - morphological characteristics of the terrain}

This part presents the only geological caracteristics of rock masses that affect the performance of drilling - blasting works.

In correlation with the genesis of the terrain, the seismotectonic characteristics of the field are defined. Basically, the zone in which the tunnel route is stretched passes through seismically active fault structures. This zone, if the intensity of seismic phenomena is taken into account, is an area with intensity VII-VIII on MCS - scale of earthquake intensity. 
This information should be taken into consideration during the design and implementation of all operations.

The tunnel route passes through the various geomorphological conditions, indicating to relatively complex requirements of this aspect. At the entrance and exit of the tunnel there is a ground slope, while the central part is the saddle. The zone of the tunnel mainly consists of filitoids, quartz-sericite-epidot schist with angle of descent of $30-35^{\circ}$. On individual cross sections of the tunnel routes defined are emphasized cracked and fault zones.

\subsection{Geotechnical characteristics of the aspect RMR classification of rock mass}

Bulk weight of rocks, in this case filitoids varies in small limits, so the average value of $\gamma=26.4 \mathrm{kN} / \mathrm{m}^{3}$ is adopted.

Having regard to the foliation for determining strength characteristics were examined a large number of samples. In filitoids, when the study was conducted, normal direction of foliation average compressive strength is $\sigma_{\mathrm{c}}=38 \mathrm{MPa}$, while parallel to the foliation obtained $\sigma_{\mathrm{c}}=84.6 \mathrm{MPa}$

When quartz-sericite schists compressive strength perpendicular to the foliation is $\sigma_{\mathrm{c}}=$ $33 \mathrm{MPa}$, while in parallel the foliation is $\sigma_{\mathrm{c}}=84.75 \mathrm{MPa}$. With this in mind anisotropy coefficient ranges from $\mathrm{K}_{\mathrm{iz}}=2.2$ to 2.5 .

- With geophysical surveys following values of seismic velocity have been defined:

in the area of the portal velocity of longitudinal elastic waves ranging from $2000-2500 \mathrm{~m} / \mathrm{s}$, and the cross of $1000-1500 \mathrm{~m} / \mathrm{s}$;

- In the list below part longitudinal elastic waves have a speed of $3000-4000$ $\mathrm{m} / \mathrm{s}$, while cross is with $1650-1860 \mathrm{~m} / \mathrm{s}$;

Speaking in general, the value of the speed of elastic waves varies from zone to zone and corresponds to the constants of the geomorphological characteristics of the field. Lower values refer to the surface area of slate, where its influence has decreased the thickness of the layer. Features of discontinuity are examined through the core drill holes. In this manner, the extent of cracking in multiple zones is defined; higher cracking occurs in the Upper zones, so that there are fewer values for the distances among cracks and RQD parameter (50\% - 60\% in the same tunnel route). The coefficient of roughness fracture walls is the JRC $=8$ at filitoids and JRC $=10$ in quartz schists. These values correspond to a class of smooth fracture surfaces. 
Strength of the fractures in walls is defined by the Schmitt's method and amounts JCS = $25 \mathrm{MPa}$ any filitoids and JCS $=33 \mathrm{MPa}$ with quartz sericite schists. While obtained from internal angle of friction ranges from $\varphi=34-35^{\circ}$ which filitoids and $\varphi=36-37^{0}$ with quartz sericite schists.

\subsection{Classification of rock masses and the choice of appropriate technology}

Based on the data obtained from the tests, a classification of rock masses is elaborated. By Bieniawski (RMR), Barton et al, was found that the route of the tunnel wall most frequently waving to the masses of III and IV category at Bieniawski (RMR $=35-43)$ (Bieniawski, 1989).

The lowest value of RMR $=35$ is in IV category, mainly in the portal and on shorter sections about fault zone, can be expected and the rock masses in the $\mathrm{V}$ category.

From these results, the blasting method can be applied as main method for excavation, whereas only in certain areas is possible to use direct scarifying and milling walls. It is recommended that the smooth blasting and the corresponding types of explosives are applied.

\section{CALCULATION OF BASIC BLASTING PARAMETERS}

The number, pattern and length of boreholes will be dictated by the physical-mechanical characteristics of the working environment, the profile size, type of explosive, way binding and initiation, as well as methods of mining.

- Depending on the position of boreholes in the work face forehead object differed are:

Cut boreholes;

- Break borehles and

- Contour boreholes (Doneva, 2013).

The selection of the cut-type and whether to apply a slant or parallel cut, depends on the depth of drilling (l), the profile size of the tunnel (S) and the coefficient of rock strength (f).

Bearing in mind that the route of the tunnel is anizotropic, we found a greater number of shares along this route.

In this paper presented are only blasting parameters for IVa class working environment. 


\subsection{Work technology in drilling and blasting}

The process of organizing the drilling and blasting operations involves successive schedule of the operations in order to effectively and safely perform these two working operations. The Figure 1 shows the model of organization of drilling and blasting in the case when, as a method of blasting the smooth blasting is applied (Dambov, 2014).

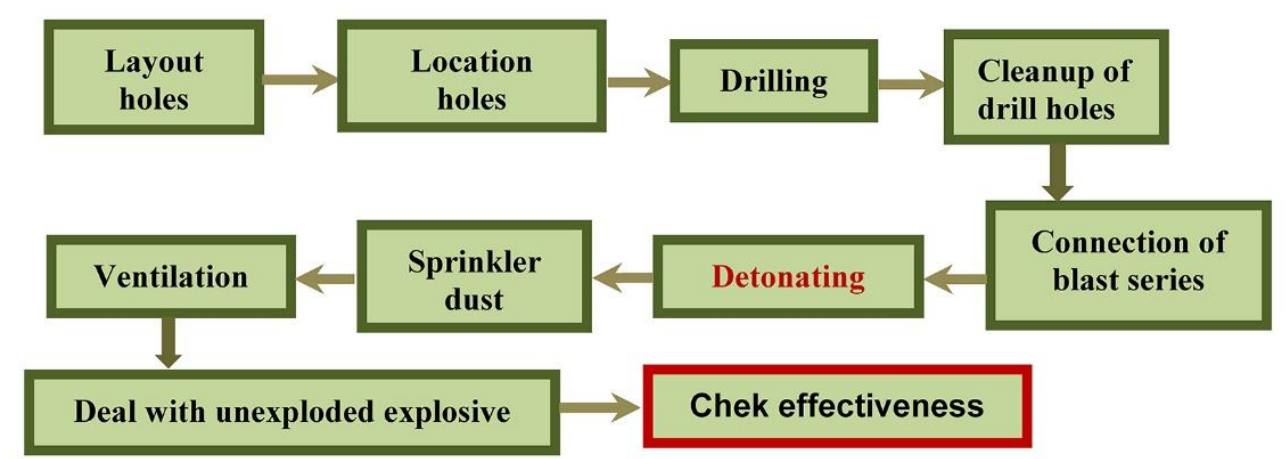

Figure 1 Model of organizing the method of smooth blasting

\subsubsection{Capacity of the drilling machines type Paramatic H205T}

Adoption of the drilling diameter 45 or $54 \mathrm{~mm}$, depends on the location and previous experience of similar working environment, as well as the possibility of investment in procurement drilling accessories and planned dynamics of progress (Sandvik Tamrock Corp., 1999). For drilling the drill type machine Paramatic H 205T, from TAMROCK Company is proposed. Drilling capacity "in situ" conditions of work is: $L_{h}=27.0 \mathrm{~m} / \mathrm{h}$.

This drill machine is equipped with two branches, which means that it can drill two wells at the same time, because the capacity is double: $\mathrm{L}_{\mathrm{ukh}}=27.0 \times 2=54 \mathrm{~m} / \mathrm{h}$

$$
L_{s h}=L_{t h} \cdot T \cdot K_{v}=54 \cdot 8 \cdot 0.9=388.8 \mathrm{~m} / \mathrm{shift}
$$

Where:

$\mathrm{K}_{\mathrm{v}}=0,9$ - coefficient of time utilization;

These values can be adjusted depending on the possibilities of the performer's security operation, technical machine capabilities and other factors. 


\subsubsection{Calculation of blasting parameters for class IVa of the working environment}

Linear charge density of the explosive $(\mathrm{kg} / \mathrm{m}$ ') - the explosive charge per meter of drilling hole. The continuous charge mode is used in cut holes and break boreholes:

$$
p=\pi d_{p}^{2} r / 4=0,965 \mathrm{~kg} / \mathrm{m}^{\prime}
$$

Where:

$$
\begin{aligned}
& \mathrm{dp} \text { - cartridge diameter, } 32 \mathrm{~mm} \text {; } \\
& \rho \text { - density of explosives, } 1.200 \mathrm{~kg} / \mathrm{m}^{3} \text {; }
\end{aligned}
$$

Borehole smooth blasting aims to preserve the rock mass surrounding the excavation stable and solid, hence the way of charging thr device with explosives is different. Here, the explosives which are used are with the diameter of the cartridge $d_{p}=28 \mathrm{~mm}$.

Linear charge with the peripheral wells are:

$$
p=\pi d_{p}{ }^{2} r / 4=0,73 \mathrm{~kg} / \mathrm{m}^{\prime}
$$

\section{Number of boreholes}

This number of boreholes wells budget is theoretical and therefore, it should be checked in situ, taking into account the specific conditions of the working environment.

The number of boreholes is:

$$
N=q \cdot S / p \cdot k_{p}=138
$$

Where:

$\mathrm{q}$ - specific consumption of explosives, $\mathrm{q}=1.25 \mathrm{~kg} / \mathrm{m}^{3}$;

$\mathrm{S}$ - profile size of the tunnel, $\mathrm{S}=64.97 \mathrm{~m}^{2}$;

$\mathrm{p}$ - intermediate linear filling of explosives in the mine series $\mathrm{p}=0.84 \mathrm{~kg} / \mathrm{m}^{\prime}$;

$\mathrm{k}_{\mathrm{p}}$ - coefficient of charge the boreholes, $\mathrm{k}_{\mathrm{p}}=0.7$.

The number of borehles refers to the total number of the profile, and the necessary drilling length is:

$$
L_{u k}=(123 \times 1.0)+(15 \times 1.5)=145.5 m^{\prime}
$$


The time for drilling is:

$$
T_{d r i l}=L_{t} / L_{h}=145.5 / 54=2.7 \mathrm{~h}
$$

\section{Calculation of explosive charge in a borehole}

Quantity of explosives in cut holes and break holes:

$$
\begin{gathered}
Q_{z}=k_{p} \cdot L \cdot p=0.66 \cdot 1.5 \cdot 0.965=0.96 \mathrm{~kg} \\
Q_{p}=k_{p} \cdot L \cdot p=0.5 \cdot 1.0 \cdot 0.965=0.48 \mathrm{~kg}
\end{gathered}
$$

Where:

$\mathrm{k}_{\mathrm{p}}$ - coefficient of charge borehole, $\mathrm{k}_{\mathrm{p}}=0.5$ to 0.9

$\mathrm{L}$ - length of boreholes, $\mathrm{L}=1.5 ; 1.0 \mathrm{~m}$

$\mathrm{p}$ - Linear charge density of the explosive per meter length boreholes, $(p=0.965$ $\left.\mathrm{kg} / \mathrm{m}^{\prime}\right)$

Quantities of explosives in boreholes for smooth (contour) blasting:

$$
Q_{r}=k_{p} \cdot L \cdot p=0.55 \cdot 1.0 \cdot 0.73=0.4 \mathrm{~kg}
$$

For this rock type the speed of elastic waves of $2500 \mathrm{~m} / \mathrm{s}$ is adopted, where explosives with a density of $1200 \mathrm{~kg} / \mathrm{m} 3$ and detonating speed of $5500 \mathrm{~m} / \mathrm{s}$ were utilized.

Given this, a type of explosive with respective blasting characteristics was adopted, packed emulsion explosives. Applied explosives should be resistant to wet conditions and the presence of water, because in some parts of the route of the tunnel these are to be expected. 
3.1.3 The parameters of smooth blasting method

It should be noted that the accrual obtained results are only tentative and that after each blasting they must be corrected on the basis of the results obtained, to make them as good as possible. In this way, we obtain the optimal parameters for smooth blasting.

The distance between the boreholes depends on the diameter, which in this case is $\mathrm{D}=$ $45 \mathrm{~mm}$ :

$\mathrm{a}=(10 \div 20) \cdot \mathrm{D}=(10 \div 20) \cdot 45=450 \sim 900 \mathrm{~mm}$

In the III and IV rosk class the distance is: $\mathrm{a}=60 \mathrm{~cm}$.

The coefficient of compaction boreholes is:

$\mathrm{m}=\mathrm{a} / \mathrm{W}=0.8 \div 1.0$

This coefficient for the III and IV class is: $\mathrm{m}=\mathrm{a} / \mathrm{W}=60 / 75=0.8$

The line of least resistance is $\mathrm{W}=360 \div 900 \mathrm{~mm}$ depending on the class working environment and type of boreholes and for Class III and Class IV is $\mathrm{W}=75 \mathrm{~cm}$.

In order to minimize the effects of mining on the surrounding rock mass (Antičević, 2004), the diameter cartridges of $28 \mathrm{~mm}$ are adopted.

Length stopper should not be less than $40 \mathrm{~cm}$, or $\mathrm{L}_{\mathrm{s} . \mathrm{sh}}=1 / 3 \mathrm{~L}_{\text {borehole. }}$.

For this method of mining and for these boreholes, a weaker explosive type GURIT (17 $\mathrm{x} 500 \mathrm{~mm}$ and $11 \mathrm{x} 460 \mathrm{~mm}$ ), is proposed.

The Table 1 shows the parameters of blasting. Tunnelling is done in three sections, so that the upper is advancing first- calotte, then the middle and at the end, the lowest part. 
Table 1 Parameters of blasting for IVa class working area

\begin{tabular}{|c|c|c|c|c|c|}
\hline \multirow[b]{2}{*}{$\begin{array}{l}\text { Detonating } \\
\text { sequence }\end{array}$} & \multirow[b]{2}{*}{ Hole type } & \multirow[b]{2}{*}{ Number } & \multirow[b]{2}{*}{$\begin{array}{l}\text { Length } \\
\text { (m) }\end{array}$} & \multicolumn{2}{|c|}{ Charing (kg) } \\
\hline & & & & $\begin{array}{c}\text { Charge } \\
\text { quantities } \\
\text { per hole }\end{array}$ & $\begin{array}{c}\text { Total charge } \\
\text { quantities }\end{array}$ \\
\hline & Hollow hole & 3 & 1.5 & & \\
\hline 1 & Cut holes & 12 & 1.5 & 0.96 & 11.52 \\
\hline 2 & Break holes & 12 & 1 & 0.48 & 5.76 \\
\hline 3 & Smooth blasting hole & 22 & 1 & 0.4 & 8.80 \\
\hline 4 & Inner-ring hole & 11 & 1 & 0.4 & 4.40 \\
\hline 1 & Smooth blasting hole & 10 & 1 & 0.4 & 4.00 \\
\hline 2 & Break holes & 20 & 1 & 0.48 & 9.60 \\
\hline 3 & Inner-ring hole & 14 & 1 & 0.4 & 5.60 \\
\hline 1 & Inner-ring hole & 22 & 1 & 0.4 & 8.80 \\
\hline \multirow[t]{2}{*}{2} & Break holes & 12 & 1 & 0.48 & 5.76 \\
\hline & TOTAL & 138 & & & 64.24 \\
\hline
\end{tabular}

\subsubsection{Ways and means of initiation}

For the initiation of boreholes, the NONEL systems are proposed. When blasting in these conditions, it is important that the interval of deceleration is sufficiently large, so that the possibility to successfully break all rock mass is guaranteed. NONEL LP is a series of detonators intended for blasting in underground conditions. Connecting with a bunch connector is the easiest and fastest way to connect the LP series in underground conditions and in groups (Figure 2).

NONEL tubes from boreholes are together in groups (a maximum of twenty of them in one group). Bunch conector connects the group with the help of part of the detonating cord. End of bunch connectors associated with Snapline 0, with these networks is ready for initiation (Dambov, 2014).

Instead of the group connector, a detonating cord can be used too, at that point the groups of the NONEL tubes are connected together by cords, in a manner that envelops each group in the node. This method is risky and requires great precision, because it may be that the shock wave fuses interrupted nonel tubes without initiating them. 


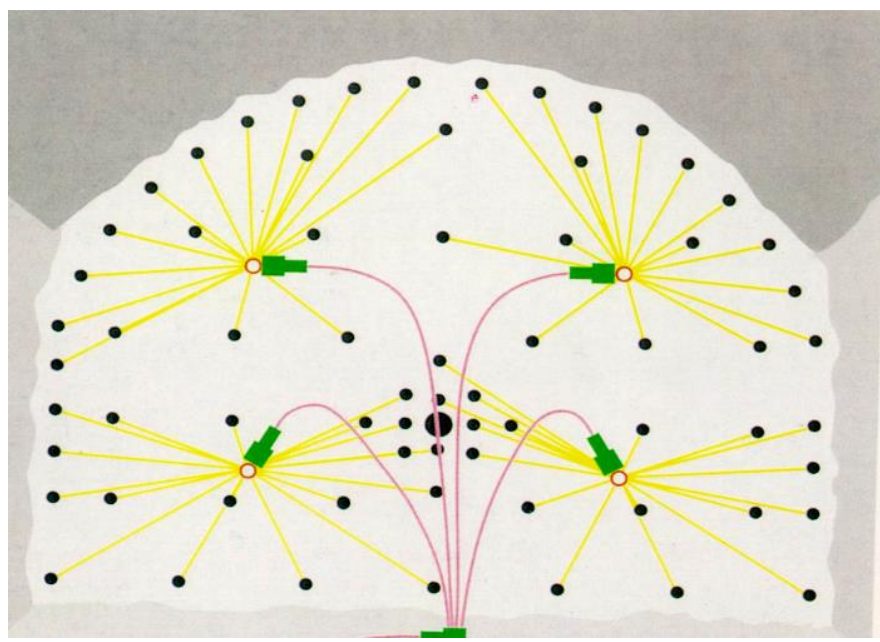

Figure 2 The way to connect the mine with the help of a series of bunch connector in tunnel construction

The Figure 3 - 5 shows the pattern of boreholes in the three sections, in the order of the excavation of the tunnel profile (DAM-EXPLO, 2014).

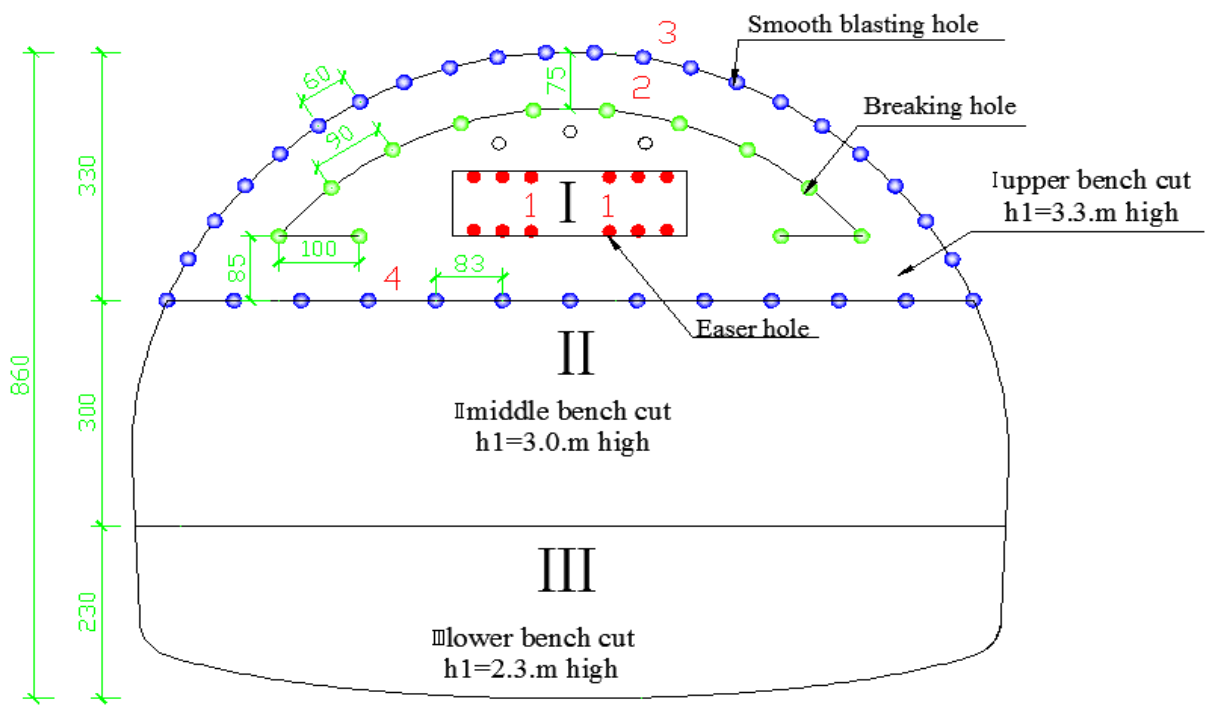

Figure 3 Schedule blast hole in the upper part of the tunnel profil 


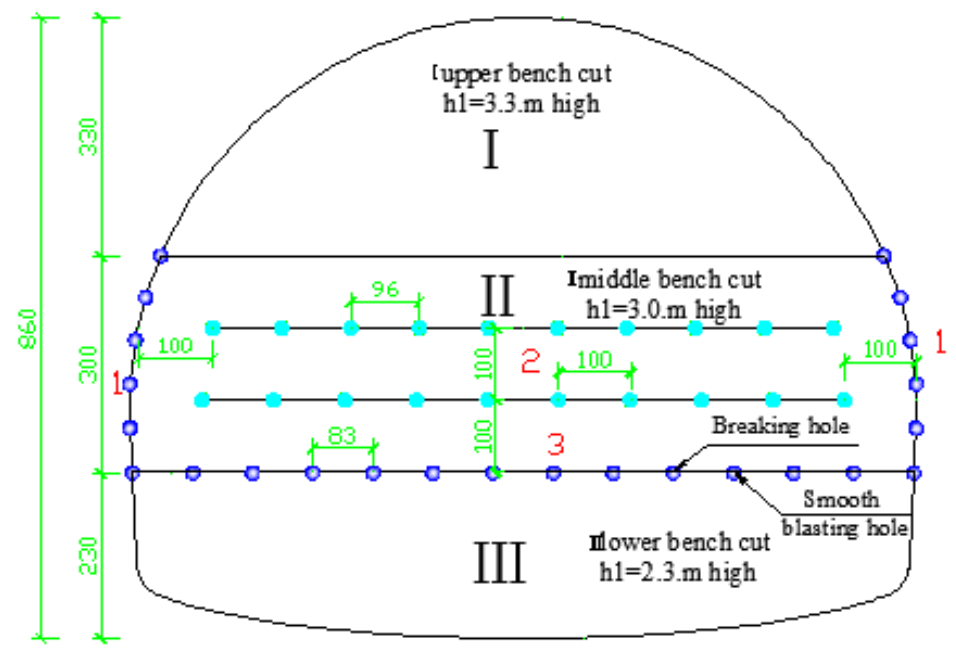

Figure 4 Schedule blast hole in the middle part of the tunnel profile

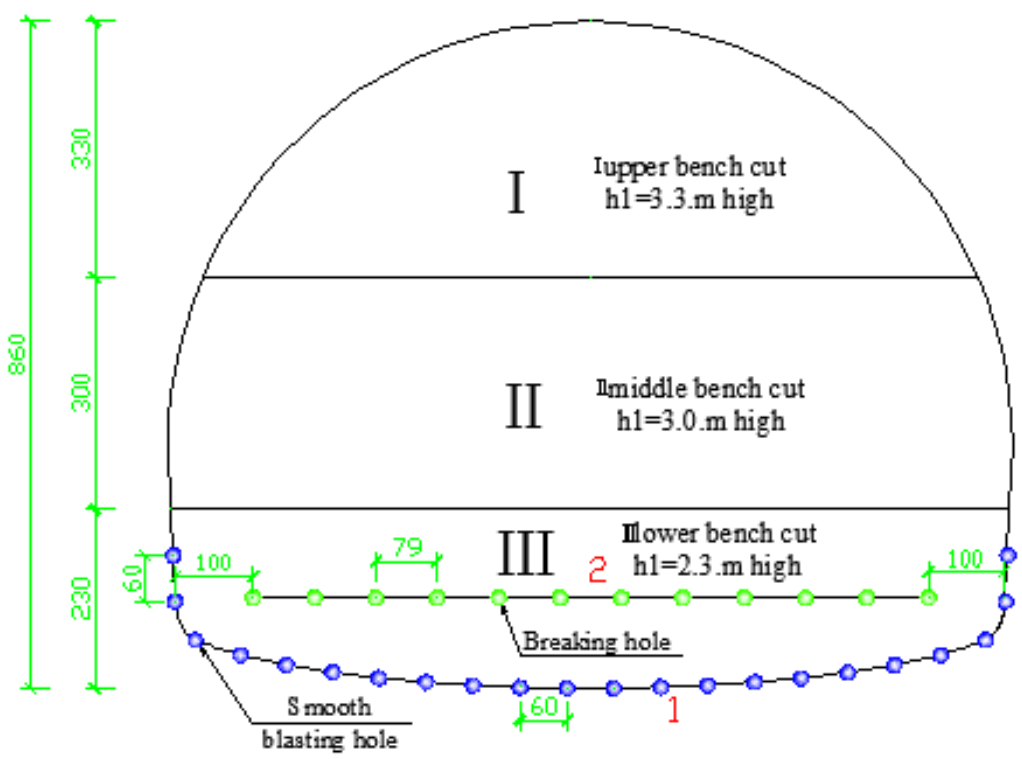

Figure 5 Schedule of the blast hole in the bottom part of the tunnel profile

Figure 6 illustrates a wedge cutting (Antičević, 1992), as well as the construction of charging in the cut boreholes, break boreholes and contour boreholes. 
a)

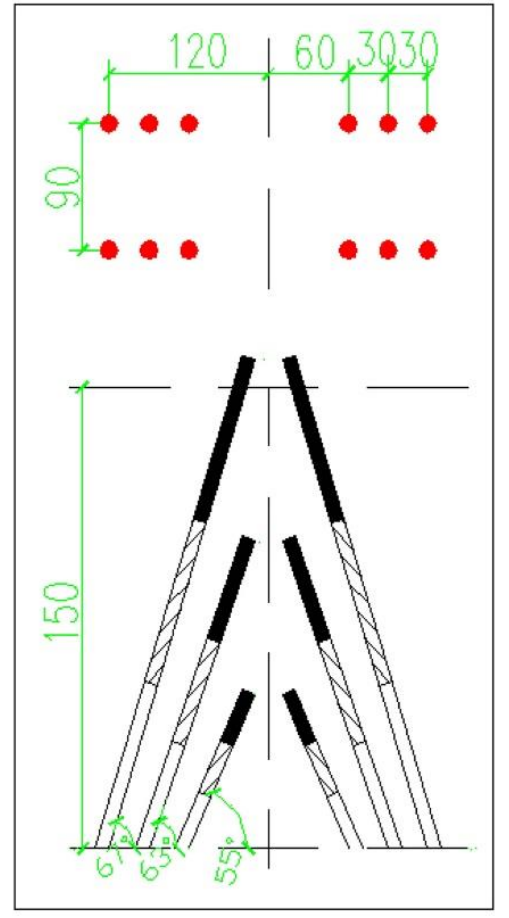

b)

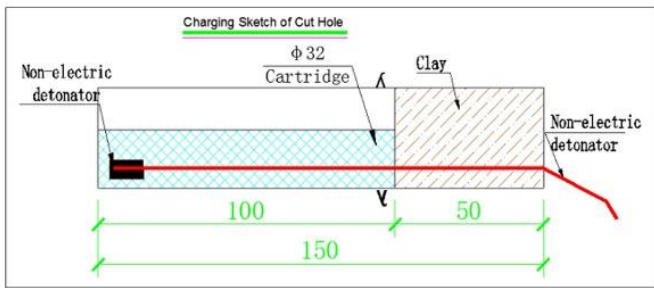

c)

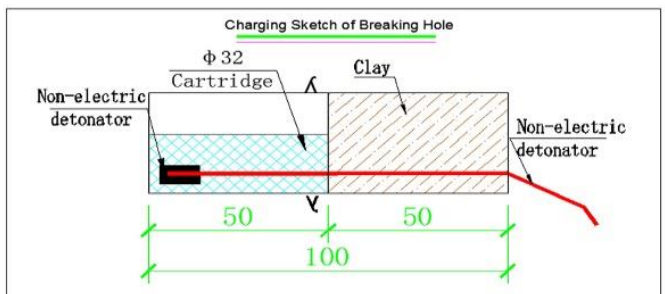

d)

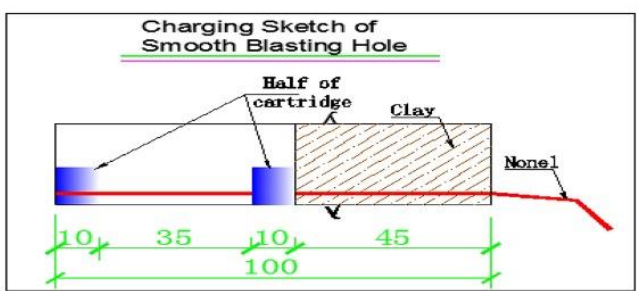

Figure 6 a) Cuting, b) Construction of charging in the cut boreholes; c) Construction of charging in break boreholes; d) Construction of charging in contour boreholes.

\section{CONCLUSION}

From the above, it can be concluded that the drilling - blasting parameters depend on the rock mass along the tunnel route. With calculation, they can only be determined orientationally, but when the site is constructed, if it turns out that the real conditions do not correspond to those of the explored, these parameters can be changed. Application of smooth blasting in order to ensure the stability of the surrounding rock mass is required when construction of the tunnel, it reduces the amount of material support for support constructions. 


\section{REFERENCES}

ANTIČEVIĆ, H. and ILIČIĆ, F. (2004) Tunnel excavation with use of controlled blasting method in proximity of constructed tunnels. In: Raw materials and coal: New perspectives. Sarajevo: IP Svjetlost, pp. 1-12.

ANTIČEVIĆ, H. (1992) Izbor najpovoljnijeg zaloma pri iskopu tunela „Tuhobić“. Thesis [BSc]. Faculty of Mining, Geology and Petroleum Engineering University of Zagreb.

ANTIČEVIĆ, H. (2011) Određivanje zone oštećenja stijenske mase pri iskopu tunela miniranjem. Thesis [Phd]. Faculty of Mining, Geology and Petroleum Engineering University of Zagreb.

BIENIAWSKI, Z.T. (1989) Engineering rock mass classifications. New York: Wiley.

DAMBOV R. (2014) Dupčenje i miniranje. Fakultet za prirodni i tehnički nauki, Štip: Goce Delchev University.

DONEVA N. (2005) Sovremeni tehnologii za izrabotka na specijalni rudarsko-inženerski objekti. Thesis [Phd]. Goce Delchev University in Shtip.

DONEVA N., DESPODOV Z. and STOJCEVA V. (2005) Application of tunnel boring machines in the mining. Podzemni radovi, 14, pp. 19-24.

DONEVA N., DAMBOV R. and HADZI-NIKOLOVA M. (2013) Rock mass clasification and their usage in mining. In: Proceeding of the XII ${ }^{\text {th }}$ national conference with international participation of the open and underwater mining of minerals. Varna, Bulgaria: pp. $279-283$.

DONEVA, N. et al. (2013) Construction of horizontal mining facilities through schist`s massive. In: 5th Jubilee Balkan Mining Congress. Ohrid, Macedonia.

DAM-EXPLO (2014) Elaborat za presmetka na dupčečko - minerski parametri pri izrabotka na tunel na Avtopat Kicevo - Ohrid.

JOVANOVIĆ, P. (1994) Proektovanje i proračun podgrade horizontalnih rudarskih prostorija - knjiga 1. University of Belgrade - Faculty of Mining and Geology.

HINDİSTAN M. A. (2004) Blasting Engineering Course Notes. H.U. Ankara.

HOEK E. (2003) Rock Engineering. Rocscience.

LAUBSCHER, D.H. (1977) Geomechanics classification of jointed rock masses - mining applications. Trans. Instn Min. Metall, 86, pp. 539-552.

MERRITT, A.H. (1972). Geologic prediction for underground excavations. In: Proc. North American. rapid excav. tunneling conf. New York: Soc. Min. Engrs, pp. 115-132. 
OLOFSSON O. S. (1990) Applied Explosives Technology For Construction and Mining. Applex, pp 131-159.

SANDVIK TAMROCK CORP. (1999) Rock Excavation Handbook. Sandvik tamrock corp.

U.S. ARMY CORPS OF ENGINEERS (1997) Engineering and Design Tunnels and Shafts in Rock. U.S. army corps of engineers.

VRKLJAN, I. (2003) Podzemne građevine i tuneli. University of Rijeka - Faculty of Civil Engineering. 